\title{
Erratum to: Name change for the Cambrian trilobite Turkestanella Repina, 1975
}

\author{
Mansoureh Ghobadi Pour
}

Published online: 15 March 2011

(C) Springer-Verlag 2011

Erratum to: Paläontol $\mathrm{Z}$

DOI 10.1007/s12542-011-0099-8

In the affiliations section on the title page, the name of the author was abbreviated incorrectly.

The author's family name should be Ghobadi Pour.

The online version of the original article can be found under doi:10.1007/s12542-011-0099-8.

M. Ghobadi Pour $(\square)$

Department of Geology, Faculty of Sciences,

Golestan University, 49138-15739 Gorgan, Iran

e-mail:m.ghobadipour@gu.ac.ir 